\title{
THE CONDITIONING OF SUICIDAL BEHAVIOR OF THE RUSSIAN YOUTH
}

\author{
Nursafa Gafurovna KHAYRULLINA \\ Tyumen Undustrial University \\ Khadiya Nurgalievna SADYKOVA \\ Tyumen Undustrial University \\ Ekaterina Vladimirovna CHUPASHEVA \\ Tyumen Undustrial University \\ Miliausha Vainerovna KINCHAGULOVA \\ Tyumen State Medical University \\ Juliya Zufarovna BOGDANOVA \\ Northern Trans-Ural State Agricultural University
}

\begin{abstract}
The paper presents the results of interviews conducted among the students of the technical university; they showed the relevance of the problem studied, allowed identifying the conditions for the formation of suicidal behavior, the causes for suicidal behavior in general, sketching a social portrait of children, adolescents, students and working youth from the point of view of their vulnerability in relation to committing suicide, and also introducing measures to prevent suicidal behavior.
\end{abstract}

Keywords: suicidal behavior, suicide prevention, family, parents, adolescents.

\section{INTRODUCTION}

In the recent two decades, sociologists have recorded a deterioration of the socio-psychological situation in Russian society (Gorshkov, \& Sheregi, 2010; Saint-Exupery, 2014). This is due to socioeconomic transformations taking place in Russia that contribute to the weakening of traditional ties between parents and children, between generations, leading to quantitative disproportions between generations, which often provoke a break in the ties between representatives of different generations (Khayrullina, \& Sadykova, 2014), misunderstandings between parents and children, adults and adolescents, teachers and students, and, as a result, to an increase in suicidal behavior among adolescents and young people.

The reforms announced in the 1980s and their implementation over the past decades have led to a decrease in the birth rate for the reasons of the uncertainty of the present and the lack of a clear picture of the future prospects in many Russian families, despite the Russian government's attempts to solve this problem through the payment of maternity capital in the recent 10 years (Ustinova, 2014). In the process of transformation of the family and its traditional culture in modern society, nuclear and small families have become widespread. The resulting weakening of the reproductive function led to quantitative disproportions between representatives of different generations. The smallest proportion in the population $(16 \%)$ is children under the age of 16 . At the same time, the proportion of young people aged 16 to 29 years is almost the same as the old-age pensioners (about 20\%), which significantly increases the demographic burden on the employable population. A similar trend was revealed by specialists of the Federal State Statistics Service of the Russian Federation. Given this conclusion, it should be emphasized that the downward trend of the population influences the change in proportions towards the increase in the number of persons over the working age (Fig. 1), despite the measures to stimulate the birth rate undertaken by the Russian government. 


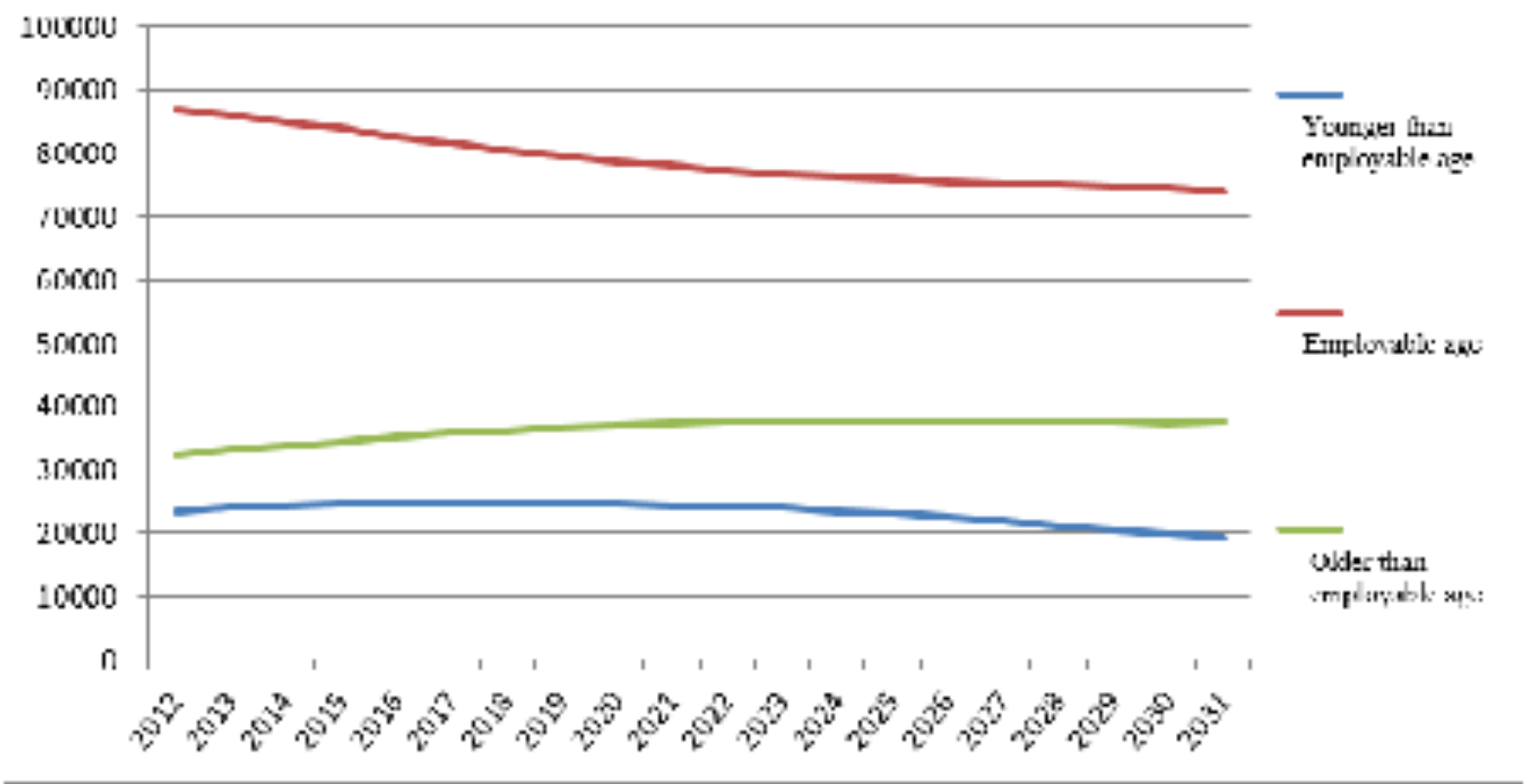

Fig. 1 Forecast of the population by age groups (at the start of each year) (Sadykova, \& Khamatkhanova, 2013)

Currently, forms of interaction such as forums, chat rooms, blogs, online games, social networks, which shape but deform individual identities of the younger generation in the first instance, have become widespread.

Information opportunities form fundamentally new forms for each generation of social identification, self-expression and the lifestyle of Russians; this has two sides of the same coin. On the one hand, the ubiquitous distribution of the Internet and other global information networks makes it possible for adolescents to show their individuality first of all, without fear for their public and private life: an adolescent at home has the opportunity to communicate with the whole world any time of the day via a personal computer, laptop, tablet or phone. It is no secret that children, pupils, high school and university students spend their free time on the Internet. And this state of constant mass communication is terribly popular not only for adolescents and young people; in this process, primary school students, their teachers, staff, and parents are actively involved. Everywhere, one can see how young parents, walking with their children, prefer to communicate in social networks, and not communicate with kids (Khayrullina, 2011).

On the other hand, given the active and widespread dissemination of up-to-date means of communication and information transfer, as well as the willingness of most parents to show that their children can have phones not worse but often better than their children's peers, it should be understood that these and other factors provide additional opportunities for adolescents to spend time (almost around the clock) in social networks. Everyone has repeatedly faced the fact that social networks do not always offer useful information; on the contrary, they inform teens and young people how they shouldn't (from the point of view of adults) spend their free time. In recent years, the social networks have involved teenagers and young people in games that contribute to the devaluation of a person's life, allowing them to take pictures and spread instant images (selfie) at risk of their lives, in order to receive likes from the people around them in Instagram, while reducing the threshold of an adolescent's acceptance of suicidal solutions. In such circumstances, it is necessary to conduct sociological monitoring of the conditions for the formation of suicidal behavior of children, adolescents, and young people and offer suicide prevention measures on a regular basis. So, in 2016, Khritinin et al. studied conditioning of suicidal behavior among students of a medical university (Khritinin, Sumarokova, Esin, Samokhin, \& Shchukina, 2016). This paper presents the results of studies on the conditioning of suicidal behavior by the example of students of the largest technical university in the capital of the Tyumen Oblast.

\section{METHODS}

Submit Date: 10.07.2018, Acceptance Date: 22.08.2018, DOI NO: 10.7456/1080SSE/145

Research Article - This article was checked by Turnitin

Copyright (C) The Turkish Online Journal of Design, Art and Communication 
The study was conducted both quantitatively and qualitatively. The quantitative method consisted in analyzing the results of a survey of the population of Tyumen and the south of the Tyumen Oblast to obtain information from the directly studied subject. The survey is an indispensable method of obtaining information about the subjective world of people, their inclinations, motifs, opinions. The regular conduct of surveys (sociological monitoring) makes it possible to trace the dynamics of changes in various spheres of public life in the country and in individual regions, provides a unique opportunity to predict the development of social processes, to identify and prevent social conflicts, including latent ones.

The survey conducted with the direct participation of the authors covered the population aged 15 to 75 years (700 people) living in Tyumen and the south of the Tyumen Oblast. In order to perform a comparative analysis of generation groups, the study was conducted on a stratified multistage sample with related parameters including gender, age, education, social and professional status, which provided an error of representativeness of no more than $5 \%$.

In addition, the quantitative method applied in this paper was the secondary analysis of sociological research data on the problems of value orientations and intergenerational interactions conducted by sociologists over the past twenty years in various regions of the Russian Federation.

The characteristic determination and analysis of the qualitative nature of the problem studied were carried out by the authors using the method of interviews with students of the Tyumen Industrial University. In January-March 2017, the interviews were conducted (the total number of respondents was 102; girls accounted for $60 \%$, boys $-40 \%$ ). In addition, the results of in-depth and biographical interviews conducted by Kazan sociologists in 2014 in the Republic of Tatarstan were analyzed. The qualitative analysis presupposes the concentration of a researcher "on the notion of a certain entity that cannot be measured, which can only be comprehended through the prism of personal experience" (Islamshina, \& Khamzina, 2014). The analysis was based on the personal experience of students aged 19 to 22 years, reproduced by them in the interview. During the interview, the authors tried to identify the specifics of socialization processes, intrafamily and intergenerational communications, implemented in the process of transfer of life experience to identify the conditioning of suicidal behavior.

\section{RESULTS}

Considering the role of the family in the formation of suicidal tendencies among Tyumen adolescents and young people, it is necessary to analyze the results of the survey conducted with the participation of the authors in 2014-2015 in Tyumen and in the south of the Tyumen Oblast. The respondents were asked the following question: "What values are important to you and what values, in your opinion, are lost today?" A list of 16 values was proposed. Let us consider an analysis of only those values that were of interest in the framework of the issue under study. The value of "traditional family's stability" was important only to a quarter of the interviewed adolescents aged 15-17 years (26.6\%); this value was named lost by about half of the respondents in this age group (42.9\%). For comparison, let us give an estimate of this value by representatives of the age group of 41-50 years; in the authors' opinion, this is the possible age of parents of 15-17-year-olds. The value of "traditional family's stability" was important for $61.8 \%$ of the respondents; the quarter of respondents in this age group $(27.6 \%)$ named this value to be lost. The next value was "mutual assistance from children (parents)" and it was important for $42.9 \%$ of $15-17$-year-olds and for $71.1 \%$ of the representatives of the age group of $41-50$ years. $14.9 \%$ of $15-17$-year-olds and $14.4 \%$ of representatives of the age group of $41-50$ years considered this value to be lost. And one more value presented for the analysis was "continuity of generations, use of experience of previous generations". This value was important only for a quarter of the interviewed adolescents aged 15-17 years (28.6\%); the number of respondents in this age group who named this value to be lost $(14.3 \%)$ was twice as poor. For $63.2 \%$ of the representatives aged 41-50 years, this value was important, and for $22.4 \%$ - it was lost.

Let us present the first results of the interviews among students of the Tyumen Industrial University. On the first question of the interview "Do you think that over the past decade there has been an increase in suicide rates among adolescents and young people aged 17-24 years?" most of the interviewed students $(86.0 \%)$ answered in the affirmative. The opposite point of view ("No, not increased") was expressed by every 10th student. And only one interview participant admitted that he 
could not answer this question. It should be noted that most of the participants in the interview argued their answer.

For the purposes of the study, it was important to find out which group was most vulnerable to suicide: children, adolescents, students or working youth. They were allowed to select no more than two categories. The analysis showed that just over half of the interviewed students (54\%) considered adolescents to be the most vulnerable category. The answers have allowed compiling a social portrait of adolescents (13-17 years old), which has the following characteristics:

- their consciousness and psyche are not fully formed and, in general, they have not fully shaped their personality; they are subject to great pressure from friends, the Internet, movies, etc.; they are easier to be influenced and other people use them pushing to suicide;

- they are most impressionable, emotional, trusting;

- they are strongly subjected to manipulation from the side, easily become slaves;

- they have transitional age and they believe that no one understands them, that everyone and everything around them are against them, and the only way out is death;

- they spend a lot of time in social networks, in which there are many factors pushing to suicide, where there is a lot of information about this topic (a girl, 24 years old, a student). It is difficult to disagree with this, because the news of the suicide is very brightly and extensively covered in Russian media, thereby creating thoughts about suicide even in those who have never thought about it;

- at the age of 13-17 years, the development of "youthful maximalism" is observed, the development of independence, there is a desire for freedom, to do what one wants; however, a limiter stands on the teenager's way to the dream - a parent with instructions that a child perceives as an attempt to "cut his or her wings" . On this basis, conflicts arise; and as an argument, the child begins to oppose his or her parents' will to his or her own life.

Every 4th student considered children under the age of 13 years to be the most vulnerable group. The social portrait includes the following characteristics:

- they do not know how to comprehend, but they themselves do everything to declare themselves;

- they are too gullible, naive; and maximalism is very developed in them;

- they spend a lot of time alone, as parents work;

- they are often intimidated and they become unprotected.

Every 5th respondent (18\%) believed that students were also a vulnerable category. This view was argued by a minimal set of characteristics: the inability to cope with problems and the fear of moving into adulthood because of the uncertainty in the future. The authors believe that the students showed solidarity with their peers, as they themselves made up this cohort.

The least vulnerable category was working youth, which, in the opinion of $3 \%$ of the interviewees, could commit suicide due to financial difficulties or problems in the family.

Then the interviewees were asked an open question, to which the authors wanted to receive a reliable answer: did they experience suicidal thoughts in the past or the present? An analysis of the answers showed that just over half of the respondents $(63 \%)$ had never experienced suicidal thoughts in the past or at the present time. The opposite opinion - yes, experienced - was expressed by just over a third of students $(37 \%)$. In the authors' opinion, not all students frankly responded to the question posed; the authors think that it was very difficult for them to step over the psychological barrier admit to strangers, adults about themselves, about their own secret feelings that they hid from their relatives, close people though in the past. The answers of two girls were indicative here, who said that "every person in life experienced a craving for death, wanted to take one's own life that considered unfair" (a 22-year-old student); "It seems to me that everyone thought about this" (a 21-year-old student).

Here are a few more answers from students who thought about it in the past or the present: "There have been thoughts about this: what will happen, but how can this solve any problems" (male, 21); "At some moments I thought that no one supported me and did not understand" (female, 20); "Sometimes such thoughts occur: after failures at school or quarrels with parents" (male, 21). In the authors' 
opinion, these fragments of the interview are useful to representatives of different ages in order to think about themselves, their friends, their children and possibly help save someone's life from a fateful step today or in the future.

At the same time, the interviewees who had never had suicidal thoughts (they were not less, but more important for all people who were not indifferent to the topic under consideration) were also interested in the answers. The conclusion formulated after analyzing all the interviews boils down to the fact that as a rule, suicidal thoughts do not arise in families where parents pay attention to their children, communicate and are interested in their problems, and children, in turn, feel the love and care of their parents. For an example, here is a fragment from one interview: "I have not experienced such thoughts and never will! My parents gave me enough attention, they supported me, I went to various hobby clubs, so I did not care about suicide" (female, 21).

Those who responded in the affirmative to the previous question had the opportunity to tell about the reasons why suicidal thoughts occurred. Students of the Tyumen Industrial University in the past or the present most often had suicidal thoughts due to the following reasons:

- conflicts with parents, teachers, friends (44.4\%);

- narcotic or alcoholic intoxication (33.3\%);

- personal experiences or problems: loneliness, lack of meaning in life (18.5\%);

- debts (3.8\%).

Here is a fragment of the interview with a girl (22 years old, a student), which clearly characterizes the role of the family in a child's life and the importance of personal contacts with parents: "In the distant past, the desire to be gone was associated with personal experiences and problems with parents, especially with the mother, who always put her personal interests over my happiness. All this was the cause of conflict, hatred, and desire to get out of life, which often was used as an argument by my mother".

$43 \%$ of students know about suicide situations among their friends, acquaintances, neighbors, and relatives. And every third of them described in detail the known cases. Simultaneously, just over half of the interviewed students (57\%) admitted that they did not know of any cases of suicide among friends, acquaintances, neighbors, and relatives.

The following (in order of decreasing importance) are the reasons for suicides among friends, acquaintances, neighbors, and relatives:

- unrequited love;

- dysfunctional family, intrafamily conflicts;

- loneliness;

- participation in suicide communities in social networks ("they were told, "if you jump off the hill, you will not fall, because you will have wings". And the guys, the schoolchildren did so");

- drugs.

Less commonly called are such reasons as: bullying peers, to spite teachers and parents who did not understand them; mental disorders and pressure; financial difficulties. Many interviewees admitted that they could not understand and accept the fact of suicide, because, in their opinion, death was incompatible with these people: "The reason is not known, no one could have guessed that such a cheerful fellow, an activist, a participant of the club of humor was capable of suicide" (21, a male student).

Next, the authors asked about the main reasons that caused suicidal behavior. The main reasons (factors) of suicidal behavior (a hierarchy of respondents' answers, in descending order) were as follows:

- unrequited love, jealousy;

- drug or alcohol intoxication;

- loneliness, unsociability, deep and wrong immersion in philosophical topics; complexes; personal experiences, the realization that life was worthless, because a person did not see further development or was not in a position to solve any problems on his or her own; loss of meaning in life; 
- conflicts in the family (quarrels with parents, the problem of "fathers and children", violence, bullying); when parents did not love their child, did not pay attention to him or her;

- conflicts with peers (misunderstanding, insults, violence, bullying); the desire to prove their uniqueness;

- media and the Internet, which were increasingly covering the problems of suicide;

- various communities in social networks and the enticement of adolescents and young people; despondency and hopelessness, proceeding from the cases and from the mouths of "opinion leaders";

- mental illness, depression, nervous breakdowns, mood swings, apathy; psychological trauma;

- problems in school (large training loads) and problems with teachers;

- youthful maximalism and adolescent stupidity, bad associations;

- debts and inability to return them;

- weak social adaptation to Western culture, provoking individualism, competition, hedonism, deformation of values.

\section{DISCUSSION}

Foreign scientists who study the development of suicidal behavior among adolescents and young people distinguish two following groups of risk factors: potential ("forming the base") and relevant (clinical). According to Bannikov et al., the most common factor of suicidal behavior is the conflict in family relations and the conflict of the personality structure. The depressive state with feelings of resentment, insult, humiliation, hopelessness, loneliness, unrequited love, anger belongs to the relevant factors influencing the development of suicidal behavior and entering into its structure. Both groups of factors are closely related, but under different conditions, they carry different load, acquire different importance (Bannikov, Pavlova, Koshkin, \& Letova, 2015: 23).

Analysis of materials of life stories and in-depth interviews collected in 2014 by Islamshina and Khamzina showed that the older generation negatively estimated the disappearance of warmth, sincerity from the practice of interpersonal communication; worried about the pragmatic relations of people, and increasing of the distance between the older and new generations in value orientations. So, a 75 year-old woman with secondary education, a pensioner wrote (and this is typical for representatives of this generation as a whole), "Our generation grew up in hardships and misery, but we loved our parents, tried not to upset them with our rash actions, were respectful of their words, opinions, and views of life. In the village, everyone tried to help each other (by joint efforts someone built a house, someone helped to bring firewood, hay). Respect for elders was a rule. In the presence of children and elders, no one spoke the foul language. I would like such traditions to be revived at the present time" (Islamshina, \& Khamzina, 2014).

Another informant, a woman, 68 years old with vocational education in construction, a pensioner, wrote, "Young people spend their spare time very poorly - I see it in my granddaughter: they do not go to the theater, museums, sometimes go to the cinema, everything that she sees is a computer monitor, a cell phone, the Internet. She has many so-called virtual friends in different networks, but we can say no real friends".

Due to the fact that for most of the interview participants the most dangerous period of life remained in the past (not distant), when suicides were most often committed, when thoughts about it retreated to the distant future, the authors found it important to ask students what measures of prevention of suicidal behavior they considered to be effective. This would allow parents, teachers, mentors to be useful, necessary for children and adolescents and to give a helping hand in a difficult hour.

\section{CONCLUSION}

An analysis of the answers of students who took part in the interview showed that almost threequarters of them considered the communication of children with their parents as the main preventive measure for preventing suicidal behavior. In the direct and indirect form, the answers were reduced to the fact that in a happy, full family, a child could not have thoughts about suicide. In such a family, parents and children constantly communicate, talk, and share their problems. "The family is the main support of a person who helps to cope with life's difficulties and only the family will be able to fully protect each of its members", said the young man (a student, 21). Through communication with their children, parents learn about the interests of their child, develop life goals and interests, show that he 
or she (the child) is needed, dear and loved. They should communicate with their children more often, call for walks, offer help, try to find out what is bothering him or her and explain that everything can be solved. They should encourage their children to have hobbies and interests to minimize free time. At the same time, they should not forget to exercise control over the child's interests, to be interested in what kind of children they are communicating with, and how relationships within teenage groups are developing. The parents should pay as much attention to their children as possible so that the latter spend as little time as possible on the Internet. It is no secret, and it has been noted above that parents often choose to communicate on the Internet, and not communicate with the child. Note that every 5th participant interviewed in a categorical form proposed to close all social networks in general, restrict access to sites where this kind of information was presented. Thus, communicating with children, it is necessary to understand what the child has on his or her mind. One should not protect him or her from peers, but try to find a compromise. Being interested in social networks, instead of interfering with personal life, one should try to do so that the child shows and tells everything by his or herself. It is required to talk more about the feelings of parents who went through a suicide of their children.

Three-quarters of the students mentioned as the next preventive measure extracurricular sessions with the school psychologist, open lessons with specialists. This measure is actualized if there is no parental support for the child; then an open propaganda in the school will be an important solution.

Every 10th respondent suggested not talking about suicide, just like pedophilia, not creating a problem of suicide in the society through the media, not discussing it on television. The same number of students offered psychological therapy, because psychologists were better versed in problems than parents who could aggravate the situation.

In conclusion, it should be noted that the data obtained by the authors during the interview allowed identifying the conditions for the formation of suicidal behavior of students of a technical university, on the basis of which it was possible to develop measures to prevent the suicidal behavior. The obtained data became the basis for further research on this issue. In the near future, the authors plan to conduct a mass survey of Tyumen schoolchildren and students on the basis of authoring tools that will offer measures to reduce suicidal thoughts among children, adolescents and youth, and let parents realize that the life of their children depends not so much on school, but first of all on them.

\section{REFERENCES}

Bannikov, G.S., Pavlova, T.S., Koshkin, K.A., \& Letova, A.V. (2015). "Potentsialnye i aktualnye faktory riska razvitiya suitsidalnogo povedeniya podrostkov (obzor literatury)" ["Potential and Actual Risk Factors for Development of Suicidal Behavior of Adolescents (Review of Literature)"]. Suitsidologiya, 6(4(21)), 21-31.

Gorshkov, M.K., \& Sheregi, F.E. (2010). "Molodezh Rossii: sotsiologicheskii portret" ["Youth of Russia: A Sociological Portrait”] (2nd ed., supplemented and amended). Moscow: TSPiM. (p. 592).

Islamshina, T.G., \& Khamzina, G.R. (2014). "Izmeneniya rossiiskogo obshchestva: pokolencheskaya perspektiva" ["Changes in Russian Society: The Generation Perspective"]. In O.A. Maksimova (Ed.), Rossiiskoe obshchestvo 2010-kh godov: svyaz vremen i pokolenii: monografiya [Russian Society of the 2010s: The Connection of Times and Generations: Monograph]. Kazan: Kazan State Technical University Publishing House. (p. 468).

Khayrullina, N.G. (2011). "Svobodnoe vremya: otsenka i mnenie tyumentsev" ["Free Time: Evaluation and Opinion of Tyumen Citizens"]. Izvestiya vysshikh uchebnykh zavedenii Sotsiologiya. Ekonomika. Politika, 1, 63-67.

Khayrullina, N.G., \& Sadykova, Kh.N. (2014). "Mezhpokolencheskaya organizatsiya sovremennogo obshchestva: regionalnyi analiz" ["Intergenerational Organization of Modern Society: Regional Analysis"]. In O.A. Maksimova (Ed.), Rossiiskoe obshchestvo 2010-kh godov: svyaz vremen $i$ pokolenii: monografiya [Russian Society of the 2010s: Connection of Times and Generations: Monograph] (pp. 76-86). Kazan: Kazan State Technical University Publishing House.

Khritinin, D.F., Sumarokova, M.A., Esin, A.V., Samokhin, D.V., \& Shchukina, E.P. (2016). "Usloviya formirovaniya suitsidalnogo povedeniya u studentov meditsinskogo vuza" ["Conditioning of Suicidal Behavior among Medical Students"]. Suitsidologiya, 7(2(23)), 49-54.

Sadykova, Kh.N., \& Khamatkhanova, M.A. (2013). "Pokolencheskie izmeneniya tsennostnykh orientatsii: metodika i rezultaty issledovaniya" ["Generation Changes in Value Orientations: Methods 
The Turkish Online Journal of Design, Art and Communication - TOJDAC

ISSN: 2146-5193, September 2018 Special Edition, p.1057-1064

and Results of Research"]. Izvestiya vysshikh uchebnykh zavedenii. Sotsiologiya. Ekonomika. Politika, 1, 58-61.

Saint-Exupery, A. (2004). "Voennyi letchik" ["Military Pilot"]. In Planeta lyudei [Planet of People] (Trans. from French, p. 384). Moscow: Eksmo. (p. 576).

Ustinova, O.V. (2014). "Gosudarstvennoe upravlenie vosproizvodstvom naseleniya" ["State Management of Population Reproduction"]. In S.S. Chernov (Ed.), Faktory ustoichivogo razvitiya regionov Rossii: monografiya [Factors of Sustainable Development of Russian Regions: Monograph] (Book 17, pp. 166-183). Novosibirsk: Publisher CRNS. 